Vol. 4: 3-9.

\title{
Nutritive value of wet distillers' solubles for pigs
}

\author{
Jarmo Valaja and Matti Näsi \\ Department of Animal Science, P.O. Box 28, FIN-00014 University of Helsinki, Finland
}

\begin{abstract}
Digestibility and nitrogen $(\mathrm{N})$ metabolism were studied to evaluate the nutritive value of wet barley distillers' solubles (DSB) from an integrated starch-ethanol process for pigs. Eight castrated male pigs (live weight $72-103 \mathrm{~kg}$ ) were used in a $8 \times 3$ cyclic change-over design, where the diets were arranged factorially $2 \times 2$. The corresponding factors were the protein source (DSB or soya bean meal (SBM)) and the protein level (131 or $162 \mathrm{~g}$ crude protein $(\mathrm{CP}) / \mathrm{kg}$ dry matter (DM)). Faeces and urine were collected in total. The four diets comprised barley, barley starch, minerals and vitamins with either DSB or SBM as the main source of protein.

The digestibility of CP $(\mathrm{p}<0.001)$ and organic matter $(\mathrm{p}<0.01)$ was higher in SBM than in DSB-based diets, but the digestibility of ash $(\mathrm{p}<0.01)$ and ether extract $(\mathrm{p}<0.001)$ was higher in DSB than in SBM-based diets. The digestibility coefficients of the nutrients calculated by regression were generally higher in SBM than in DSB. The digestibility of CP was 0.865 in DSB and 0.902 in SBM.

The pigs on SBM-based diets retained more $(\mathrm{p}<0.001)$ and excreted less $\mathrm{N}$ in urine $(\mathrm{p}<0.001)$ than the pigs on DSB-based diets. The nitrogen balance parameters were closely related to lysine supplies, which were higher in SBM-based diets.
\end{abstract}

Key words: swine, digestibility, protein metabolism, distillery by-product, soya bean meal

\section{Introduction}

Wet distillers' solubles (DSB) are a proteinous feed fraction derived from an integrated starchethanol process using barley as a raw material. They mainly consist of the water-soluble part of the distilling residue. The proximate crude protein (CP) content of DSB is $360 \mathrm{~g} / \mathrm{kg}$ dry matter (DM) and their amino acid composition reflects that of barley (Huhtanen and Näsi 1992).
Because of the suspicion that their high ash content may be harmful to pigs, DSB are primarily used as a protein supplement in the diets of dairy cows and growing cattle. Moreover, most of the nutritional research into DSB has been conducted on dairy cows (Huhtanen and Miettinen 1992) or growing cattle (Huhtanen et al. 1991). The reported digestibilities of the nutrients in dried DSB from a similar process in pigs were quite high, ranging from 0.740 to 0.876 (Näsi 1989), whereas those of the nutrients in 
Valaja, J. \& Näsi, M.: Nutritive value of wet distillers' solubles for pigs

semi-solid DSB (DM $550 \mathrm{~g} / \mathrm{kg}$ ) from dehulled barley were clearly lower, especially for crude protein (Näsi 1985).

Owing to the inconsistency in the digestibility coefficients of the above experiments and to the lack of knowledge about the digestibility and protein utilization of the wet form of DSB, we set out to determine and compare the nutritive value of wet distillers' solubles and soya bean meal for pigs. Chemical composition, digestibility and protein balance responses were used as comparable parameters.

\section{Material and methods}

The digestibility and protein utilization experiment was conducted with eight castrated Landrace $\times$ Yorkshire male pigs to evaluate and compare the nutritive value of DSB and soya bean meal (SBM). The average initial weight of the pigs was 72.4 (SE 1.84) kg and the final weight 102.9 (SE 1.83) kg. The experimental design was an $8 \times 3$ cyclic change-over, and the diets were arranged $2 \times 2$ factorially, with protein source (DSB or SBM) and protein level (131 or $162 \mathrm{~g}$ crude protein (CP)/kg dry matter (DM)) as factors. The pigs were kept in metabolism cages througout the trial, which allowed separate total collection of faeces and urine. Each experimental period lasted ten days: five days of adjustment and five days of collection. The daily feeding scale was from 2.4 to $2.5 \mathrm{~kg}$ DM. The daily allowance was fed in two equal portions at 8.00 and 15.00 hours and was mixed with water before feeding. The pigs had ad libitum access to water.

The four experimental diets consisted of barley, barley starch and DSB or SBM as a protein supplement (Table 1). Minerals and vitamins were added to the diets to meet the requirements of growing pigs (Salo et al. 1990). All the diets contained a constant amount of barley $(757 \mathrm{~g} /$ $\mathrm{kg} \mathrm{DM}$ ) and either DSB or SBM at two levels to provide 131 or $162 \mathrm{~g} \mathrm{CP} / \mathrm{kg}$ DM. Barley starch
Table 1. Dietary ingredients and calculated chemical composition of the diets.

\begin{tabular}{lrrrr}
\hline Diet & $1^{3}$ & $2^{3}$ & 3 & 4 \\
\hline Content in dry matter, g/kg & & & & \\
$\quad$ Barley & 757 & 757 & 757 & 757 \\
Distillers' solubles & 119 & 218 & - & - \\
Soya bean meal & - & - & 78 & 142 \\
Barley starch & 96 & - & 134 & 71 \\
Minerals and vitamins $^{1}$ & - & - & 25 & 25 \\
Trace elements ${ }^{2}$ & 14 & 13 & - & - \\
Limestone $_{\text {Dicalcium phosphate }}$ & 8 & 12 & - & - \\
Chemical composition: & 6 & - & 6 & 5 \\
Content in dry matter, g/kg & & & & \\
Crude protein & 131.3 & 162.1 & 131.7 & 162.9 \\
Lysine & 4.7 & 5.9 & 5.6 & 7.6 \\
Methionine + cystine & 8.9 & 11.1 & 8.1 & 9.5 \\
Threonine & 5.9 & 6.8 & 5.5 & 7.0 \\
Calcium & 8.3 & 8.3 & 8.3 & 8.2 \\
Phosphorus & 5.3 & 5.5 & 5.8 & 6.1 \\
\hline
\end{tabular}

1. Provided the following per kg diet DM: Fe $80 \mathrm{mg}, \mathrm{Zn}$ $100 \mathrm{mg}, \mathrm{Mn} 40 \mathrm{mg}, \mathrm{Cu} 6 \mathrm{mg}$, Se $0.1 \mathrm{mg}$ and vitamin A $5000 \mathrm{IU}$, vitamin D $1500 \mathrm{IU}$ and vitamin E $25 \mathrm{mg}$.

2. Provided the following per kg diet DM: Fe $80 \mathrm{mg}, \mathrm{Zn}$ $100 \mathrm{mg}, \mathrm{Mn} 40 \mathrm{mg}$, Cu $6 \mathrm{mg}$, Se $0.1 \mathrm{mg}$.

3. Diets 1 and 2 were supplemented with vitamin mixture to provide the following per $\mathrm{kg}$ diet DM: vitamin A 5000 $\mathrm{IU}$, vitamin D $1500 \mathrm{IU}$ and vitamin E $25 \mathrm{mg}$.

served as a balancer. DSB were manufactured from barley at the Alko Ltd. Koskenkorva factory, which employs an integrated starch-ethanol process as described in detail by Näsi (1988). After the distilling process, DSB were separated by centrifugation from distillers' solids and evaporated to a DM content of $360 \mathrm{~g} / \mathrm{kg}$. To ensure quality during the trial, it was delivered frozen from the factory and thawed in the experimental stall.

The proximate composition of the feeds and faeces was analysed by standard methods (AOAC 1984). The amino acid composition of barley, SBM and DSB was determined by high performance liquid chromatography (HPLC) after hydrolysis with $6 \mathrm{~N} \mathrm{HCl}$ at $110^{\circ} \mathrm{C}$ for $23 \mathrm{~h}$. The fatty acid composition of DSB was analysed by gas chromatography (AOAC 1984). 


\section{AGRICULTURAL SCIENCE IN FINLAND}

Vol. 4: 3-9.

The apparent digestibility coefficients of the nutrients in the experimental feeds (DSB and SBM) were calculated by multiple regression equation (Schneider and Flatt 1975):

$$
\mathrm{Y}=\mathrm{aX} \mathrm{X}_{1}+\mathrm{bX}_{2}
$$

In the equation, Y stands for the total amount of digested nutrient from the diet $(\mathrm{g} / \mathrm{d})$, and $\mathrm{X}_{1}$ and $\mathrm{X}_{2}$ for the amounts of diet nutrients from the basic feed (barley, barley starch and minerals and vitamins) and protein supplement (DSB or SBM), respectively, and a and b for the digestibility coefficients of the nutrients from the basic feed or protein supplement, respectively. In the calculations, barley starch was assumed to be totally digested (Graham et al. 1989). The regression method was preferred to the difference method, because it is more suitable for estimating digestibility coefficients when the amount of experimental feed in a diet is low (Fan and Sauer 1994). The feeding value of the experimental feeds was calculated as feed units (FU) according to Salo et al. (1990) or as net energy (NE) according to CVB (1991). The data were subjected to analysis of variance using the general linear model (GLM) procedure of SAS (1985). The model included the effect of period, animal and diet. The diet effect was further separated into the three orthogonal contrast: $\mathrm{C} 1=$ DSB vs. SBM-based diets, C2 = low protein diets vs. high protein diets and $\mathrm{C} 3=$ interaction $\mathrm{C} 1 \times \mathrm{C} 2$.

\section{Results}

DSB contained DM 358 and SBM $869 \mathrm{~g} / \mathrm{kg}$ (Table 2). The CP content of SBM was higher than that of DSB (494 and $319 \mathrm{~g} / \mathrm{kg} \mathrm{DM}$, respectively), but DSB contained twice as much ash as SBM (135 and $64 \mathrm{~g} / \mathrm{kg}$ DM, respectively). The amino acid profile of SBM was better than that of DSB, the lysine contents being 64 and $39 \mathrm{~g} /$ $160 \mathrm{~g} \mathrm{~N}$, respectively. The ether extract of DSB
Table 2. Analysed chemical compositions of barley and protein supplements.

\begin{tabular}{|c|c|c|c|}
\hline Feed & Barley & $\begin{array}{c}\text { Soya bean } \\
\text { meal }\end{array}$ & $\begin{array}{c}\text { Wet distillers' } \\
\text { solubles }\end{array}$ \\
\hline Dry matter, g/kg & 859 & 869 & 358 \\
\hline Ash, g/kg DM & 21 & 64 & 135 \\
\hline Crude protein," & 123 & 494 & 319 \\
\hline Ether extract," & 33 & 71 & 89 \\
\hline Crude fibre," & 54 & 71 & 17 \\
\hline $\mathrm{N}$-free extracts, " & 769 & 300 & 440 \\
\hline \multicolumn{4}{|c|}{ Amino acids, g/160 g N } \\
\hline Lysine & 34 & 64 & 39 \\
\hline Threonine & 40 & 48 & 44 \\
\hline Methionine & 26 & 23 & 20 \\
\hline Cystine & 42 & 29 & 48 \\
\hline Histidine & 20 & 25 & 26 \\
\hline Leucine & 68 & 78 & 53 \\
\hline Isoleucine & 40 & 51 & 33 \\
\hline Phenylalanine & 36 & 53 & 41 \\
\hline Arginine & 51 & 77 & 52 \\
\hline \multicolumn{4}{|c|}{ Fatty acids, g/100 g ether extract } \\
\hline $\mathrm{C} 14: 0$ & 0.4 & & \\
\hline $\mathrm{C} 15: 0$ & 0.1 & & \\
\hline C16:0 & 26.4 & & \\
\hline C17:0 & 0.1 & & \\
\hline C18:0 & 2.4 & & \\
\hline C18:1w9 & 11.6 & & \\
\hline C18:2w6 & 47.6 & & \\
\hline $\mathrm{C} 18: 3 w 3$ & 6.1 & & \\
\hline C20:0 & 0.2 & & \\
\hline C20:1w9 & 0.8 & & \\
\hline $\mathrm{C} 22: 0$ & 0.2 & & \\
\hline C22:1w11 & 0.1 & & \\
\hline $\mathrm{C} 24: 0$ & 0.1 & & \\
\hline
\end{tabular}

mainly contained C16:0, C18:1w9 and C18:2w6 fatty acids $(26.4,11.6$ and $47.6 \mathrm{~g} / 100 \mathrm{~g}$ ether extract, respectively).

One pig was excluded from the experiment because of leg injury, and another one was excluded from periods 1 and 2 because of poor appetite. This resulted in fewer observations for diets $2(n=4), 3(n=4)$ and $4(n=5)$. Otherwise the pigs completed the experiment successfully. Palatability problems could not be related to the protein sources, because diet rejections occurred for both protein supplements. The average DM 
Valaja, J. \& Näsi, M.: Nutritive value of wet distillers' solubles for pigs

Table 3. Apparent faecal digestibility of experimental diets and nitrogen $(\mathrm{N})$ metabolism and utilization in the pigs (LS means).

\begin{tabular}{|c|c|c|c|c|c|c|c|c|}
\hline $\begin{array}{l}\text { Diet } \\
\text { Protein source } \\
\text { " level, g/kg DM }\end{array}$ & $\begin{array}{c}1 \\
\text { DSB } \\
131\end{array}$ & $\begin{array}{c}2 \\
\text { DSB } \\
162\end{array}$ & $\begin{array}{c}3 \\
\text { SBM } \\
131 \\
\end{array}$ & $\begin{array}{c}4 \\
\text { SBM } \\
162\end{array}$ & SEM & $\mathrm{C} 1$ & $\mathrm{C} 2$ & $\mathrm{C} 3$ \\
\hline Dry matter & 0.839 & 0.822 & 0.844 & 0.841 & 0.0024 & $* *$ & $*$ & * \\
\hline Organic matter & 0.861 & 0.843 & 0.865 & 0.860 & 0.0023 & $* *$ & $* *$ & o \\
\hline Ash & 0.480 & 0.528 & 0.435 & 0.493 & 0.0077 & $* *$ & $* * *$ & NS \\
\hline Crude protein & 0.795 & 0.804 & 0.830 & 0.844 & 0.0051 & $* * *$ & NS & NS \\
\hline Ether extract & 0.587 & 0.627 & 0.497 & 0.539 & 0.0077 & $* * *$ & $* *$ & NS \\
\hline Crude carbohydrates & 0.884 & 0.866 & 0.885 & 0.878 & 0.0023 & o & $* *$ & o \\
\hline $\mathrm{N}$ intake, g/day & 50.6 & 61.2 & 51.5 & 63.9 & 0.32 & $* *$ & $* * *$ & o \\
\hline Faecal N, “ & 10.3 & 11.9 & 8.7 & 10.0 & 0.21 & $* * *$ & $* * *$ & NS \\
\hline N absorbed, " & 40.3 & 49.3 & 42.8 & 53.9 & 0.46 & $* * *$ & $* * *$ & NS \\
\hline $\mathrm{N}$ digestibility & 0.795 & 0.804 & 0.830 & 0.844 & 0.0051 & $* * *$ & NS & NS \\
\hline $\mathrm{N}$ in urine, $\mathrm{g} /$ day & 23.1 & 29.0 & 21.9 & 25.0 & 0.16 & $* * *$ & $* * *$ & $* * *$ \\
\hline Urea- $\mathrm{N}$ in urine, " & 17.5 & 22.6 & 17.6 & 19.2 & 0.44 & $*$ & $* * *$ & * \\
\hline $\mathrm{N}$ retained, g/day & 17.2 & 20.3 & 20.9 & 28.9 & 0.51 & $* * *$ & $* * *$ & ** \\
\hline of intake & 0.340 & 0.332 & 0.406 & 0.452 & 0.0074 & $* * *$ & o & * \\
\hline of absorbed & 0.428 & 0.413 & 0.489 & 0.537 & 0.0071 & $* * *$ & NS & $* *$ \\
\hline
\end{tabular}

DSB = wet distillers' solubles, $\mathrm{SBM}=$ soya bean meal, $\mathrm{SEM}=$ standard error of the means. $\mathrm{C} 1=$ protein source (DSB diets vs. SBM diets), $\mathrm{C} 2=$ protein level (131 vs. $\left.162 \mathrm{~g} \mathrm{CP} \mathrm{kg}^{-1} \mathrm{DM}\right)$ and C3 = interaction $\mathrm{C} 1 * \mathrm{C} 2$.

intake of the experimental diets was $2406 \mathrm{~g} /$ day, being higher for the pigs on SBM diets than for those on DSB diets ( $<<0.01 ; 2435$ and $2377 \mathrm{~g} /$ day, respectively), because the number of observations on the diets was unequal.

The diets composed of different protein supplements were highly digestible (Table 3 ). The apparent digestibility of DM $(\mathrm{p}<0.01)$, organic matter $(\mathrm{OM})(\mathrm{p}<0.01)$ and $\mathrm{CP}(\mathrm{p}<0.001)$ was higher in the diets composed of SBM than in those composed of DSB, but ash $(\mathrm{p}<0.01)$ and ether extracts $(\mathrm{p}<0.001)$ were better digested in DSB than in SBM-based diets.

The digestibilities of the nutrients calculated by regression were higher for SBM than for DSB (Table 4). DM, OM, ash, CP and crude carbohydrates were digested better in SBM than in DSB. The calculated energy values for DSB and SBM were 1.067 and 1.165 FU/kg DM, respectively according to Salo et al. (1990) or 10.27 and 10.64 MJ NE/kg DM, respectively according to CVB (1991).

There was a marked difference in $\mathrm{N}$ utilization between the pigs on the diets composed of DSB and SBM (Table 3). N retention $(\mathrm{p}<0.001)$ was higher and $\mathrm{N}$ excretion $(\mathrm{p}<0.001)$ lower for the pigs on SBM than on DSB-based diets. Also the proportion of $\mathrm{N}$ retained per intake or per absorption differed between the pigs fed the diets composed of SBM or DSB ( $\mathrm{p}<0.001)$. A higher protein level improved daily $\mathrm{N}$ retention $(\mathrm{p}<0.001)$. Protein source and level interacted with each other in most of the protein utilization parameters, because the enhancement in the protein utilization was higher when the amount of SBM was increased in the diets. Increased protein supplementation improved the proportion of $\mathrm{N}$ retained per intake or absorption for the pigs on SBM-based diets $(\mathrm{p}<0.05)$ but not for those on DSB-based diets. 


\section{AGRICULTURAL SCIENCE IN FINLAND}

Vol. 4: 3-9.

Table 4. Apparent faecal digestibility calculated by regression and feed value of wet distillers' solubles and soya bean meal.

\begin{tabular}{lcccc}
\hline Feeds & DSB & SE & SBM & SE \\
\hline Digestibility: & & & & \\
Organic matter & 0.850 & 0.0453 & 0.901 & 0.0859 \\
Ash & 0.674 & 0.0561 & 0.999 & 0.2238 \\
Crude protein & 0.865 & 0.0654 & 0.902 & 0.0676 \\
Ether extracts & 0.774 & 0.0497 & 0.753 & 0.1578 \\
Crude carbohydrates & 0.844 & 0.0527 & 0.915 & 0.0859 \\
Feed value: & & & & \\
FU'/kg DM & 1.067 & & 1.165 & \\
NE 2 MJ/kg DM & 10.27 & & 10.64 & \\
DCP, g/kg DM & 288 & & 345 & \\
DCP, g/FU & 270 & & 382 & \\
\hline
\end{tabular}

DSB = wet distillers' solubles, $\mathrm{SBM}=$ soya bean meal. $\mathrm{DCP}=$ digestible crude protein. $\mathrm{SE}=$ standard error of the estimate. 1. Feed unit $=0.7$ starch equivalent. 2 . NE calculated according to CVB (1991).

\section{Discussion}

The present experiment showed clearly that DSB are highly digestible for pigs. The apparent digestibility coefficients obtained from this trial were consistent with the results of Näsi (1989). In contrast to our results, Näsi (1985) obtained much lower digestibility coefficients of $\mathrm{CP}$ in DSB (0.626). The process, however, was different in that experiment because barley was only dehulled before distilling. The digestibility of $\mathrm{CP}$ in wet distillers' solids from the same process is very similar to that of CP in DSB (Näsi and Aimonen 1992, Valaja and Näsi, manuscript Valaja, unpublished), because the feed fractions originate from the same process.

Conventional distiller feeds have very variable and usually rather low digestibility of $\mathrm{CP}$, ranging from 0.469 to 0.775 in the former experiments (Salo 1978, Peers et al. 1978, Zoiopoulos et al. 1983a, 1983b, Näsi, manuscript 1984). Cromwell et al. (1993) stated that overheating during drying is the main reason for the variation in nutritive value. Further, the high fibre content reduces the nutritive value of distiller feeds for monogastrics (Cromwell et al. 1993, Näsi 1984).
The $\mathrm{N}$ balance parameters were closely related to dietary lysine supplies, which were lower in DSB-based diets. Lysine is the first limiting amino acid in DSB, as it occurs in its raw material, barley (Fuller et al. 1979). N retention per intake or per absorption increased by 0.05 units, when more SBM was added to the diets; the addition of DSB had, however, no effect on the parameters. The bulk of the increased protein supply from DSB was excreted in urine. The most efficient way to improve the protein utilization of distiller feeds is by supplementing synthetic amino acids (Valaja 1992).

The content of sulphur-containing amino acids (methionine + cystine) was very high in both protein supplements. This resulted in an imbalance of methionine + cystine per lysine in all diets. The analysed content of methionine and cystine in the protein supplements was higher than that of the feeds in the former analyses (Salo et al. 1990, Huhtanen and Näsi 1992). Since amino acid analysis is a complex procedure and oxidation prior acid hydrolysis is needed for the sulphur-containing amino acids, the possibility of analytical error cannot be totally ruled out.

DSB have mainly been used in the diets of ruminants, as the high ash content of DSB is believed to be harmful to pigs. DSB have high 


\section{AGRICULTURAL SCIENCE IN FINLAND}

Valaja, J. \& Näsi, M.: Nutritive value of wet distillers' solubles for pigs

phosphorus, potassium and sodium contents (Näsi 1985). However, the content of these minerals in the diets is well under the toxious levels reported in ARC (1980).

According to this trial, DSB are highly digestible for pigs. However, its use as the only protein supplement is limited, because the lysine content is low with respect to the requirement of the pigs. Further, the production experiments are needed to establish the full nutritive value of DSB.

\section{References}

ARC 1981. The nutrient requirements of pigs. Agricultural Reseach Council, Commonwealth Agricultural Bureaux, Slough. $304 \mathrm{p}$.

AOAC 1984. Official methods of analysis. 14th edn. Association of Official Analytical Chemist, Arlington, Virginia.

Cromwell, G.L., Herkelman, K.L. \& Stahly, T.S. 1993. Physical, chemical, and nutritional characteristics of distillers dried grains with solubles for chicks and pigs. Journal of Animal Science 71: 679-686.

CVB 1991. Veevoedertabel. Centraal Veevoederbureau. The Netherlands. ISBN 90-72839-13-7.

Fan, M.Z. \& Sauer, W.C. 1994. Determination of apparent ileal amino acid digestibility in low-protein feedstuffs with the direct, difference, and regression method. In: Souffrant, W.-B. \& Hagemeister, H. (eds.). Proceedings of the 6th International Seminar on Digestive Physiology in Pigs, Bad Doberan, Germany. EAAP-publication n:o 80 , vol. 1, p. 103-106.

Fuller, M.F., Livingstone, R.M., Baird, B.A. \& Atkinson, T. 1979. The optimal amino acid supplementation of barley for growing pig. 1. Response of nitrogen metabolism to progressive supplementation. British Journal of Nutrition 41: 321-331.

Graham, H., Fadel, J.G., Newman, C.W. \& Newman, R.K. 1989. Effect of pelleting and B-glucanase supplementation on the ileal and faecal digestibility of a barleybased diet in the pig. Journal of Animal Science 67: 12931298.

Huhtanen, P., Khalili, H. \& Näsi, M. 1991. A comparison of untreated and formaldehyde-treated barley distiller's solubles and rapeseed meal as protein supplements in dairy cows given grass silage ad libitum. Journal of Agricultural Science in Finland 63: 455-463.

- \& Miettinen, H. 1992. Milk production and concentrations of blood metabolites as influenced by the level of wet distiller's solubles in daily cows receiving grass silage-based diet. Agricultural Science in Finland 1: 279290.

- \& Näsi, M. 1992. Evaluation of feed fractions from integrated starch-ethanol production from barley in diets of cattle, pigs and poultry. Proceedings of Distillers Feed Conference, Cincinnati, Ohio. Vol. 47: 67-86.

Näsi, M. 1984. Evaluation of barley distillers dried grains with soluble, and condensed distillers solubles in the diet of growing pigs. Journal of Agricultural Science in Finland 56: 221-226.

- 1985. Distillers feeds from various grains as protein sources for pigs. Journal of Agricultural Science in Finland 57: 255-262.

- 1988. Evaluating barley feed fractions from integrated ethanol-starch production in the diets of ruminants. Journal of Agricultural Science in Finland 60: 701-709.

- 1989. Barley feed fractions from integrated ethanolstarch process in diets of pigs. Journal of Agricultural Science in Finland 61: 441-450.

- \& Aimonen, E. 1992. Evaluation of undehydrated barley feed fractions and dried oat feed fractions from integrated starch-ethanol process in diets of growing pigs. Agricultural Science in Finland 1: 291-301.

Peers, D.G., Hillyer, G.M. \& MacAndrew, A. 1978. The evaluation of grain distillers evaporated spent wash in diets for growing pigs. Animal Production 26: 396-397.

Salo, M.-L. 1978. Vehnärankkijauhon rehuarvo lihasikojen ruokinnassa. Journal of the Scientific Agricultural Society of Finland 42: 291-295.

- , Tuori, M. \& Kiiskinen, T. 1990. Rehutaulukot ja ruokintanormit. Helsinki. 70 p.

SAS 1985. SAS User's Guide: Statistics. 956 p. 5 th Ed. SAS Institute Inc, Cary, NC, USA.

Schneider, B.H. \& Flatt, P.W. 1975. The evaluation of feeds through digestibility evaluation. 423 p. University of Georgia Press, Athens, Georgia.

Valaja, J. 1992. The effect of supplementation of liquid and crystalline lysine to barley-distillers solids diet on the performance and carcass quality of pigs. Agricultural Science in Finland 1: 559-567.

Zoiopoulos, P.E., English, P.R. \& Topps, J.H. 1983a. Fibrous agro-industrial by-products as protein sources for bacon pigs. 1. Assessment of performance, digestibility and carcass quality. Zeitschrift für Tierphysiologie, Tierernăhrung und Futtermittelkunde 49: 210-218.

- , Topps, J.H. \& English, P.R. 1983b. Fibrous agroindustrial by-products as protein sources for bacon pigs. 2. Study of digestion with pigs cannulated at the ileum. Zeitschrift für Tierphysiologie, Tierernährung und Futtermittelkunde 49: 219-228. 
Vol. 4: 3-9.

\title{
SELOSTUS
}

\section{Tiivistetyn tärkkelysrankin ravintoarvo lihasikojen rehuna}

\author{
Jarmo Valaja ja Matti Näsi \\ Helsingin yliopisto
}

Tutkimuksessa selvitettiin tärkkelys-etanolituotannosta saatavan kuivaamattoman tiivistetyn tärkkelysrankin rehuarvoa lihasikojen ruokinnassa. Kokeessa verrattiin tiivistetyn tärkkelysrankin ja soijarouheen ravintoaineiden sulavuutta ja valkuaisen hyväksikäyttöä. Koe-eläiminä oli kahdeksan leikkosikaa (maatiainen $\times$ yorkshire), jotka painoivat kokeen alussa 72 ja lopussa $105 \mathrm{~kg}$. Neljä koedieettiä sisälsivät tutkittavia valkuaisrehuja kahdella tasolla sekä lisäksi ohraa, ohratärkkelystä sekä kivennäisiä ja vitamiineja.

Sekä tiivistetty tärkkelysrankki- että soijarouhepohjaisten dieettien ravintoaineet sulivat hyvin. Soijarouheen ravintoaineet sulivat kuitenkin hiukan pa- remmin kuin tiivistetyn tärkkelysrankin. Tiivistetyn tärkkelysrankin valkuaisen sulavuus oli 0,865 ja soijarouheen 0,902 . Soijarouhepohjaista dieettiä saaneet siat pidättivät typpeä paremmin elimistöönsä ja erittivät vähemmän typpeä virtsan mukana kuin tiivistettyä tärkkelysrankkia syöneet siat, koska soijarouheen valkuaisen aminohappokoostumus oli parempi kuin tiivistetyn tärkkelysrankin. Soijarouhe ja tiivistetty tärkkelysrankki sisälsivät lysiiniä 64 ja $39 \mathrm{~g} / \mathrm{kg}$ raakavalkuaista.

Kokeen perusteella tiivistetty tärkkelysrankki on hyvin sulavaa. Alhainen lysiinipitoisuus kuitenkin rajoittaa sen käyttöä pelkkänä valkuaisrehuna. 